\title{
Hyacinth Macaw (Anodorbynchus byacintbinus) nests in a mosaic of protected areas in Carajás and surrounding areas, state of Pará, Brazil
}

\author{
Grace Ferreira da Silva ${ }^{1,2,6}$, Flávia Torres Presti ${ }^{2,3}$, Juliana Rechetelo ${ }^{2}$, Neiva Maria Robaldo Guedes ${ }^{2,4}$, \\ Adriane Pinto Wasko ${ }^{1} \&$ Reginaldo José Donatelli5
}

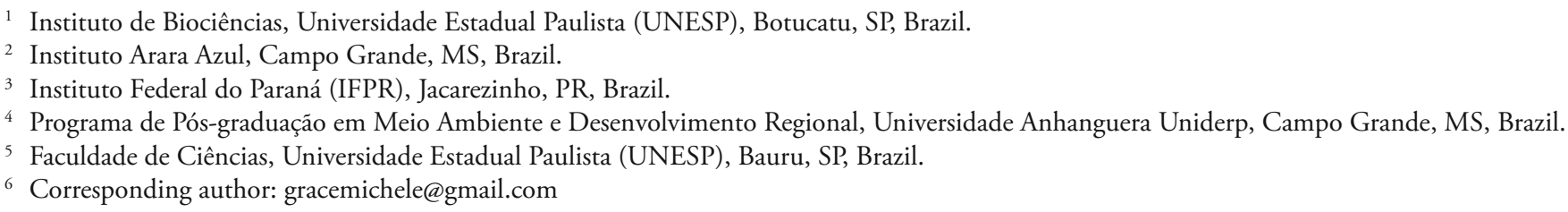

Received on 23 October 2018. Accepted on 22 July 2019.

\begin{abstract}
Natural history studies can provide information that can be used in species conservation and management. The present study provides information about the nests and nest sites of Hyacinth Macaws (Anodorhynchus hyacinthinus) in a mosaic of protected areas in Carajás and surrounding areas in the Amazon region of the state of Pará, Brazil. Data were collected during four expeditions conducted in 2007, 2008, 2013 and 2014. A total of 66 tree cavities were monitored, and 28 of these were used by Hyacinth Macaws. In addition, 38 breeding events were recorded (some nests were active in multiple seasons), and 17 eggs and 33 nestlings were observed. Environmental variables for the 24 cavities that were actively used by Hyacinth Macaws were evaluated. Most of the nest cavities were located in Sterculia sp. trees (86.6\%) and in open areas (e.g., near pastures). Nesting tree and cavity measurements were variable, but the mean diameter at breast height of the trees containing Hyacinth Macaw nest cavities was larger than that reported from other regions, such as the Pantanal. The present study describes the unique ecology and life history of Hyacinth Macaws in Carajás, for which information is scarce. This information will facilitate the conservation and management of Hyacinth Macaws and can be used locally for environmental education.
\end{abstract}

KEY-WORDS: breeding ecology, endangered bird, hollow-nesting bird, Psittacidae, Sterculia sp.

\section{INTRODUCTION}

The Hyacinth Macaw Anodorhynchus hyacinthinus is the largest member of the Psittacidae and has suffered major population declines over the last 30 years (BirdLife International 2016). The species is classified as "Endangered" in CITES Appendix I and as "Vulnerable" by the IUCN (BirdLife International 2018), owing to illegal trade, local hunting, and habitat loss (Mittermeier et al. 1990, Guedes 1993, Snyder et al. 2000). The species was once widely distributed in Brazil, yet most of the remaining individuals occur in three major regions. Current populations can be found in the eastern Amazon (Tocantins and Pará states), in central Brazil (Maranhão, Piauí, Bahia, Tocantins, Goiás, Mato Grosso, and Minas Gerais states), and in the Pantanal (Mato Grosso and Mato Grosso do Sul states; BirdLife International 2016); the latter region contains the largest remaining population (Munn et al. 1987, Guedes et al. 2008, Pivatto et al. 2008, BirdLife International 2016).
Although long-term studies of Hyacinth Macaws have been conducted in the Pantanal region (Guedes 1993, Antas 2004, Guedes 2009), little is known about the population status, breeding ecology, or life-history of the species in other locations (Snyder et al. 2000, Dornas et al. 2013). Vegetation structure and composition differ in the three main areas where Hyacinth Macaws occur, and consequently, resource availability varies (Presti et al. 2015). Furthermore, given the current trends of land use in the Amazon Forest, with high rates of deforestation and habitat loss, it is necessary to understand the ecological requirements of Hyacinth Macaw in the Amazon region.

One region in the Amazon, Serra dos Carajás, is a complex of protected areas in the locality between the Xingu and Tocantins Rivers that harbors a permanent breeding population of Hyacinth Macaws, which may be the largest in the Amazon region (Presti et al. 2009, Rosa 2016). The region is mostly covered by tropical rainforest, with dense populations of large trees, including Sterculia spp., Euxylophora paraensis, Brazil Nut Trees, 
Bertholletia excelsa, and Parkia spp, that are important for the nesting of the local Hyacinth Macaw population (Presti et al. 2009, Rosa 2016). However, despite the importance of Serra dos Carajás to the maintenance of Hyacinth Macaw populations, little is known about its ecological requirements in the region (Presti et al. 2009). Accordingly, the aim of the present study was to describe the ecology and life-history of Hyacinth Macaws in the mosaic of protected areas in the Amazon region of Carajás, state of Pará, Brazil.

\section{METHODS}

\section{Study area}

We conducted surveys in the mosaic of protected areas in Carajás and the surrounding private properties, southeast of Pará $\left(06^{\circ} 00^{\prime} S ; 50^{\circ} 30^{\prime} \mathrm{W}\right.$, Fig. 1). Carajás contains six protected areas: three National Forests (FLONA), one indigenous reserve, one Environmental Protected Area (APA), and one Biological Reserve, which together form a large forest fragment of $-12,000 \mathrm{~km}^{2}$ (Martins et al. 2012). The vegetation in the region can be divided in two main categories: dense and open tropical rainforest (known locally as "Floresta Ombrófila Densa" and "Floresta Ombrófila Aberta"), which covers the majority of the area, and Savanna (metalophylic vegetation, known locally as canga; Martins et al. 2012). We monitored three sites within the region, site 1: Rio Itacaiúnas; site 2: Canaã dos Carajás; and site 3: FLONA Itacaiúnas.

Site 1 was located between FLONA Carajás and FLONA Tapirapé-Aquiri. There were six vegetation types in the area: a) dense tropical rainforest, which features epiphytes and arboreal strata reaching $35 \mathrm{~m}$, as well as highly dense understory strata; b) lowland open tropical rainforest; c) open tropical rainforest, which is characterized by the presence of palm trees, including Babassu Palm (Orbignya phalerata); d) open tropical forest with lianas; e) riparian forest, which features fast-growing vegetation, few canopy trees, intermediate strata with palm trees, and a high density of woody and herbaceous lianas; and f) savannas (ICMBio 2009).

Site 2 was located in the southernmost part of FLONA Carajás and the surrounding properties. Five municipalities are adjacent to the mosaic of protected areas in Carajás: Marabá, Parauapebas, Canaã dos Carajás, Água Azul do Norte, and São Félix do Xingu. The main economic activities of the region are livestock rearing and agriculture (Palheta-da-Silva 2004, Coelho et al. 2008), and the major threats to the protected areas are deforestation, wildfires, and mining. Although this area was extensively cleared for livestock and agriculture, the site contained large flocks of Hyacinth Macaws (Presti et al. 2009).

Site 3 was located in the northern area of FLONA Itacaiúnas and the surrounding properties. The site was highly modified and included many private properties

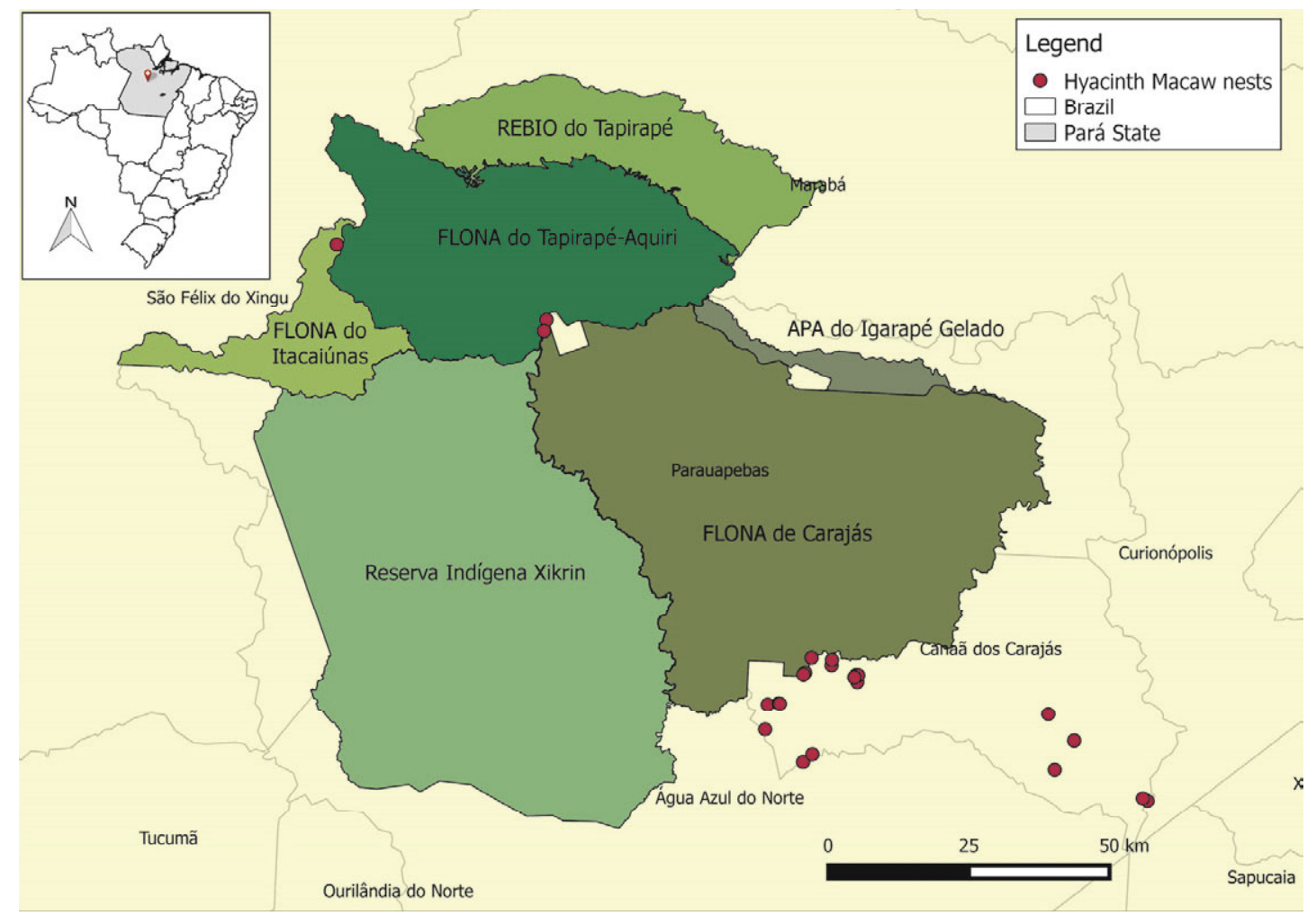

Figure 1. Hyacinth Macaw Anodorhynchus hyacinthinus nests monitored in a mosaic of protected areas and surroundings. Green areas represent the six protected areas in Carajás. 
and pastures, and the FLONA contained large numbers of cattle. Natural vegetation cover was only observed on slopes and uneven terrain (G.F.S., pers. obs.).

\section{Data collection}

We conducted four approximately 30-day-surveys in the study area, in 2007, 2008, 2013, and 2014. We monitored each site from one up to four times between September and October of each year, resulting in a total of $458 \mathrm{~h}$ of fieldwork (visits at site 1 in 2013 and 2014 was 96 h; at site 2 in 2007, 2008, 2013 and 2014 was 338 $\mathrm{h}$; and at site 3 in 2013 was $24 \mathrm{~h}$ ). Expeditions depended on availability of boats, $4 \mathrm{WD}$ vehicles, and authorized teams. As such, site 2 that included several farms and readily accessible roads, was visited more frequently than the other two sites.

\section{Bird sampling}

Fieldwork involved searching for and describing cavities used by Hyacinth Macaws. We used tracks, creeks, and roads inside the properties to approach potential nesting trees, and information from local inhabitants was also important in locating nests. Only cavities that contained macaws or signs of the presence of Hyacinth Macaw, such as bite marks or remnant pieces of food, feathers, or feces, were monitored (Guedes 1993, Guedes \& Seixas 2002).
We classified the cavities as active (containing eggs or nestlings), inactive (without breeding activity at the time of the survey, but active in other seasons, either before or after the current season), or potential (without breeding activity, but with signs of Macaw presence).

We monitored cavities that contained stingless bees (Trigona sp.) but we did not monitor cavities that contained Honey Bees (Apis mellifera) or were otherwise inaccessible, due to structural issues (main trunk broken), even if the cavities had been previously active or Hyacinth Macaws were observed nearby. Some nest cavities were used for more than one season, and each observation of breeding activity was considered and counted as a breeding event.

We accessed cavities using climbing and rappelling techniques (Guedes 1993, Guedes \& Seixas 2002). If nesting trees and cavities were active during at least one breeding season, 10 environmental variables were measured for each nesting tree and nest cavity (Table $1)$. We counted the number of eggs and nestlings. We collected environmental variables for 24 nesting trees, except for diameter at breast height $(\mathrm{DBH})$, which was measured for 20 nesting trees.

\section{Data analysis}

Descriptive statistics (mean and standard deviation, SD) were calculated for the environmental variables collected

Table 1. Nest tree and cavity variables measured for trees containing Hyacinth Macaw nests at three sites in the mosaic of protected areas in Carajás, Pará state, Brazil.

\begin{tabular}{|c|c|c|}
\hline \multicolumn{2}{|l|}{ Variable } & \multirow{2}{*}{$\begin{array}{l}\text { Description } \\
\text { Tree species in which nest cavity was located. }\end{array}$} \\
\hline Nest tree & Species & \\
\hline & Tree height & $\begin{array}{l}\text { Height of nesting tree }(\mathrm{m}) \text {, measured from the entrance of the nest to the } \\
\text { ground using a measuring tape; the entrance to the top of the tree was } \\
\text { estimated visually. Both measurements were summed. }\end{array}$ \\
\hline & Cavity height & $\begin{array}{l}\text { Height of the cavity entrance }(\mathrm{m}) \text {, measured from the entrance of the nest to } \\
\text { the ground using a measuring tape. }\end{array}$ \\
\hline & $\mathrm{DBH}$ & $\begin{array}{l}\text { Diameter at breast height }(\mathrm{cm}) \text {, measured as the circumference of the tree at } \\
\text { breast height using a measuring tape. }\end{array}$ \\
\hline & Location & $\begin{array}{l}\text { Location of the nesting tree: open area, edge of the forest, or forest interior (> } \\
5 \mathrm{~m} \text { from the edge, Guedes 1993). }\end{array}$ \\
\hline \multirow[t]{5}{*}{ Nest cavity } & Entrance width & Entrance width $(\mathrm{cm})$, measured from lateral edges of the cavity with a ruler. \\
\hline & Entrance height & $\begin{array}{l}\text { Entrance height }(\mathrm{cm}) \text {, measured from the top edge to the bottom edge of the } \\
\text { cavity using a ruler. }\end{array}$ \\
\hline & Cavity width & $\begin{array}{l}\text { Width of the cavity }(\mathrm{cm}) \text {, measured from the entrance to the back wall of the } \\
\text { cavity using a ruler. }\end{array}$ \\
\hline & Cavity depth & $\begin{array}{l}\text { Depth of the cavity }(\mathrm{cm}) \text {, measured from the bottom edge of the entrance to } \\
\text { the cavity floor using a ruler. This measurement was not taken for all nests. }\end{array}$ \\
\hline & Origin & $\begin{array}{l}\text { Most likely origin of cavity: broken branch, fungal action, or other birds (e.g., } \\
\text { members of the Picidae family). }\end{array}$ \\
\hline
\end{tabular}


at the active nest cavities. The relationship between tree and cavity height was evaluated using Pearson's correlation. All statistical analyses were performed using $\mathrm{R}$ version 3.1.1 (R Core Team 2014).

\section{RESULTS}

We monitored a total of 66 potential cavities in 2007 , 2008, 2013, and 2014. Of these, 28 were actively used by Hyacinth Macaws (Fig. 1). Eight cavities were active more than once, with six used for two breeding seasons and two used for three breeding seasons, and the other 20 nests were only used for a single breeding season. In total, 38 breeding events were recorded (Table 2 ).

We recorded cavities in 10 tree species, whereas breeding events were only recorded in seven (Table 3). At site 1, we registered nest cavities in five tree species, with breeding events only observed in Cariniana sp. and Parkia sp. At site 2, we registered nest cavities in six tree species, mostly $(86.6 \%)$ in Sterculia sp. (likely S. pruriens), and all the cavities recorded at site 3 were found in B. excelsa (Table 3).

Most of the nests $(87.5 \%, n=21)$ were located in

Table 2. Nest cavities, breeding events, eggs, and nestlings of Hyacinth Macaws in the mosaic of protected areas in Carajás, Pará state, Brazil, registered during surveys in 2007, 2008, 2013 and 2014. Cavities: total number of cavities monitored; inaccessible: number of cavities with Hyacinth Macaws nearby but which could not be monitored due to the presence of Honey Bees (Apis mellifera) or due to the main trunk being broken; stingless bees: number of cavities with stingless bees; Other species: number of other bird species breeding in or using the cavity; $n$ active cavities: cavities with eggs or nestlings; and breeding events/eggs/nestlings: number of breeding events, eggs, and nestlings per year/survey and total. (-) Not monitored in that season.

\begin{tabular}{|c|c|c|c|c|c|c|c|c|c|c|}
\hline \multirow{2}{*}{$\begin{array}{l}\text { Site } \\
\text { (effort) }\end{array}$} & \multirow{2}{*}{ Cavities } & \multirow{2}{*}{$\begin{array}{l}\text { Inaccessible } \\
\text { (trunk/Apis) }\end{array}$} & \multirow{2}{*}{$\begin{array}{l}\text { Stingless } \\
\text { bees }\end{array}$} & \multirow{2}{*}{$\begin{array}{l}\text { Other } \\
\text { species }\end{array}$} & \multirow{2}{*}{$\begin{array}{l}n \text { active } \\
\text { cavities }\end{array}$} & \multicolumn{5}{|c|}{ Breeding events/eggs/nestlings } \\
\hline & & & & & & Total & 2007 & 2008 & 2013 & 2014 \\
\hline $\begin{array}{l}\text { Site } 1 \text { - Rio Itacaiúnas } \\
(2013 \text { - 2014, } 96 \text { h) }\end{array}$ & 17 & $0 / 0$ & 0 & 0 & 2 & $2 / 2 / 1$ & - & - & $1 / 0 / 1$ & $1 / 2 / 0$ \\
\hline $\begin{array}{l}\text { Site } 2 \text { - Canaã dos Carajás } \\
(2007 \text { to } 2014,338 \text { h) }\end{array}$ & 45 & $8 / 2$ & 2 & 1 & 25 & $35 / 15 / 30$ & $9 / 0 / 9$ & $12 / 4 / 12$ & $7 / 2 / 6$ & $7 / 9 / 3$ \\
\hline $\begin{array}{l}\text { Site } 3 \text { - FLONA Itacaiúnas } \\
(2013,24 \text { h) }\end{array}$ & 4 & $3 / 0$ & 0 & 0 & 1 & $1 / 0 / 2$ & - & - & $1 / 0 / 2$ & - \\
\hline Total & 66 & 13 & 2 & 1 & 28 & $38 / 17 / 33$ & $9 / 0 / 9$ & $12 / 4 / 12$ & $9 / 2 / 9$ & $8 / 11 / 3$ \\
\hline
\end{tabular}

Table 3. Tree species containing Hyacinth Macaw cavities (active, inactive, and potential; see Methods for details) in the mosaic of protected areas in Carajás, Pará state, Brazil.

\begin{tabular}{llccccc}
\hline Species & Local name & Site 1 & Site 2 & Site 3 & No. cavities & $\begin{array}{c}\text { No. breeding } \\
\text { events }\end{array}$ \\
\hline Bagassa guianensis & Tatajuba & 1 & - & - & 1 & 0 \\
$\begin{array}{l}\text { Bertholletia excelsa } \\
\text { Cariniana sp. }\end{array}$ & Castanheira-do-Pará & 5 & - & 4 & 9 & 1 \\
Ceiba pentandra & Estopeira & 1 & - & - & 1 & 1 \\
Euxylophora paraensis & Amaraúma & & 1 & - & 1 & 1 \\
Helicostylis tomentosa & Inharé & 8 & - & - & 8 & 0 \\
Parkia aff. gigantocarpa & Fava-grande & - & 1 & - & 1 & 0 \\
Parkia sp. & Faveiro & - & 1 & - & 1 & 1 \\
Schizolobium sp. & Paricá & 2 & 1 & - & 3 & 1 \\
Sterculia sp. & Axixá & - & 2 & - & 2 & 1 \\
Total & & - & 39 & - & 39 & 32 \\
\hline
\end{tabular}


open areas, and the remaining $4.2 \%(n=1)$ and $8.3 \%(n$ $=2$ ) of the nests were located at the forest edge or in the forest interior, respectively. At site 2 , which contained most of the monitored cavities, $95.2 \%(n=20)$ of the cavities were located in open areas (i.e., pasture). In addition, most of the cavities $(70.9 \%, n=17)$ had originated from broken branches, and the remaining cavities $(29.1 \%, n$ $=7$ ) originated from the effects of fungi or bird activity. At site 2, 76.1\% of nest cavities originated from broken branches.

We collected environmental variables for 24 of the 28 nest cavities. Tree height ranged from 17 to $38 \mathrm{~m}$, and cavity height ranged from 7.5 to $28.8 \mathrm{~m}$, whereas entrance width varied between 10 and $51 \mathrm{~cm}$ and entrance height varied between 17 and $137 \mathrm{~cm}$ (Table 4). Cavity height was positively correlated with tree height $(r=0.57, P=$ $0.010)$ and DBH $(r=0.48, P=0.048)$, and entrance width was correlated with entrance height $(r=0.53, P=$ 0.010).

A total of 17 eggs (four in 2008, two in 2013, and 11 in 2014) and 33 nestlings ( 9 in 2007, 12 in 2008, 9 in 2013, and 3 in 2014) were observed during the study. The median clutch size was 2 eggs per nest, and the number of nestlings varied from 1 to 2 per nest. Furthermore, competition for cavities was observed in 4 situations and involved 5 additional species, namely Honey Bees, stingless bees (Trigona sp.), Red and Green Macaws (Ara chloroptera), Scarlet Macaws (Ara macao), and Collared Forest Falcons (Micrastur semitorquatus).

\section{DISCUSSION}

In the present study in the Carajás region, the nest cavities of Hyacinth Macaws were predominantly located in Sterculia sp. trees. This finding agrees with a previous report by Presti et al. (2009), who found that $S$. pruriens was the preferred tree species for Hyacinth Macaws nesting in Canaã dos Carajás. In the Pantanal region, most Hyacinth Macaw nests are found in Panama Trees (S. apetala; $94 \%$ in south Pantanal, 91\% in north
Pantanal, and $86 \%$ in the Poconé sub-region; Guedes 1993, Pinho 1998, Pinho \& Nogueira 2003, Antas et al. 2010). Although other species, including $E$. paraensis and $B$. excelsa, also exhibited indications of being used by Hyacinth Macaws, there were no or few breeding events recorded in these species. However, other tree species have been reported to contain Hyacinth Macaw nest cavities at other locations. For example, in Pantanal, Hyacinth Macaw nest cavities were recorded in Albizia niopioides, Albizia inundata, Pacara Eearpod Trees Enterolobium contortisiliquum, and Vitex cymosa. In a central region of Brazil, Hyacinth Macaws were found to occasionally use nest cavities in palm trees, including Moriche Palm Mauritia vinifera (Munn et al. 1987, Antas et al. 2010). Because Hyacinth Macaws depend on softwood trees and pre-existing cavities to breed, the presence of trees with cavities suitable for breeding is vital for the persistence of Hyacinth Macaw populations (Presti et al. 2009). Additional studies are needed to evaluate the availability of nesting trees and nest cavities in these regions.

Most nest cavities we recorded in our study were located in open areas, frequently in grazed areas. This has also been reported for Hyacinth Macaws in the Carajás region (Presti et al. 2009). Hyacinth Macaws may choose to use open areas to optimize a variety of factors, such as visibility, food accessibility, and ease of mobility, since Hyacinth Macaws are relatively large-bodied (Pinho \& Nogueira 2003, Presti et al. 2009). Nonetheless, forested environments seem to be more suitable for Macaws than cleared areas (Conrado 2015). Hyacinth Macaws may tolerate a certain level of landscape degradation at locations near forested areas and may use cleared areas for breeding activities since cleared areas have improved visibility (Guedes 1993, Conrado 2015). The forested areas in Carajás play an important role in maintaining the Hyacinth Macaw population in the area, as these areas provide breeding and feeding resources, thereby allowing the macaws to use the surrounding areas, including degraded, grazed, and cleared areas (Conrado 2015). Therefore, the conservation of Carajás protected areas is vital to the conservation of the local Hyacinth Macaw population.

Table 4. Characteristics of active Hyacinth Macaw nests $(n=24)$ in the mosaic of protected areas in Carajás, Pará state, Brazil.

\begin{tabular}{lccc}
\hline Variable & Mean \pm SD & Min & Max \\
\hline Tree height $(\mathrm{m})$ & $25.9 \pm 5.7$ & 17.0 & 38.0 \\
Cavity height $(\mathrm{m})$ & $16.8 \pm 4.9$ & 7.5 & 28.8 \\
Entrance width $(\mathrm{cm})$ & $20.9 \pm 10.4$ & 10.0 & 51.0 \\
Entrance height $(\mathrm{cm})$ & $48.1 \pm 35.7$ & 17.0 & 137.0 \\
Cavity width $(\mathrm{cm})$ & $61.2 \pm 21.9$ & 33.0 & 110.0 \\
Cavity depth $(\mathrm{cm})$ & $34.8 \pm 53.8$ & 0.0 & 270.0 \\
Diameter at breast height $(\mathrm{cm})$ & $366.1 \pm 243.8$ & 205.0 & 995.0 \\
\hline
\end{tabular}


Most of the cavities documented in Carajás originated from broken branches. This has also been reported for Hyacinth Macaws in north Pantanal (81\% of cavities SESC RPPN [Private Natural Heritage Reserve] and Pirizal, in Poconé sub-region). However, the trend was not observed in south Pantanal (Nhecolândia), where fungi, together with termites and ants, were responsible for the formation of $56 \%$ of cavities (Guedes 1993, Pinho \& Nogueira 2003, Antas et al. 2010). The availability of cavities is greater in old-growth forests (Mannan et al. 1980), and the greater cavity availability may allow Macaws to use cavities produced directly by decay processes and mechanical damage and to avoid infected cavities (Cockle et al. 2012). The conservation of well-structured forests with high cavity availability is crucial for the persistence of Hyacinth Macaws in the wild (Cockle et al. 2012).

The mean height of nesting trees was higher in Carajás than that reported for other regions (north Pantanal SESC: $18.7 \pm 3.3 \mathrm{~m}$; Poconé sub-region: 16.3 $\pm 4.3 \mathrm{~m}$, and south Pantanal/Nhecolândia: $14.3 \pm 2.0$ m; Guedes 1993, Pinho \& Nogueira 2003, Antas et al. 2010). The same pattern was observed for mean cavity height, which was higher in Carajás than in north Pantanal SESC $(9.6 \pm 2.2 \mathrm{~m})$, the Poconé sub-region $(5.8 \pm 6.9 \mathrm{~m})$, and south Pantanal/Nhecolândia $(7.9 \pm$ $2.0 \mathrm{~m}$, Guedes 1993, Antas et al. 2010). Because cavity height was positively correlated with tree height in the present study, the higher mean heights of nesting trees and cavities are likely a consequence of the structure of the Carajás forest itself, which includes dense and tall vegetation (Antas et al. 2010, Martins et al. 2012).

Nest cavity features may have significant effects on nest success and survival (Britt 2011). Cavities maintain a microclimate and protect eggs and chicks from extreme weather and predation (Britt 2011). DBH was greater in Carajás than other regions, likely due to forest structure. Hyacinth Macaws will use any available cavities that are large enough to hold nestlings. Sterculia apetala trees, for instance, must attain a DBH of $60 \mathrm{~cm}$ or greater in order to shelter Hyacinth Macaw nestlings (Santos-Jr. et al. 2007). Although the physical structure of nest cavities is important, other factors, such as the availability of food and water, and predator detection, may also influence the use of specific trees by Hyacinth Macaws (Sedgwick \& Knopf 1992, Antas et al. 2010).

Some nest cavities were active during more than one breeding season in Carajás. Similarly, $30 \%$ of the cavities in south Pantanal and Nhecolândia were used more than once (Guedes 2004). This could indicate fidelity to the breeding site. Because of their size, large Macaws may have fewer suitable available cavities and exhibit moderate nest-site fidelity (Britt 2011). Further studies that mark individual Hyacinth Macaws should be conducted to evaluate the nest fidelity of the species.

Competition for cavities was observed in Carajás, as previously reported for other sites in Pantanal (Guedes 1993, Pinho \& Nogueira 2003, Guedes 2009, Antas et al. 2010). Interspecific cavity competitors may be twice as likely to cause nest failure, when compared to predation (Britt 2011). Although Rio Itacaiúnas (site 1) is a preserved area, deforestation can become an issue in other sites, since it may reduce the number of cavities in the area. Secondary cavity-nesters, such as Hyacinth Macaws, depend on pre-existing cavities, and a limitation in this resource can negatively influence populations (Cornelius et al. 2008). Hyacinth Macaws may share cavities with stingless bees (Trigona sp.), but never with Honey Bees, which are aggressive and do not tolerate the presence of Macaws in their cavities. Stingless bees, however, may also become competitors over time, as the hive grows and makes the cavity unsuitable for Macaws (Guedes 1993 \& 2004, Santos-Jr. et al. 2007).

Most of the surveys in the present study were conducted in October. However, the nest cavities were observed with eggs and nestlings in different stages of development, which indicated asynchrony in the breeding activity of Hyacinth Macaws. This finding is in agreement with previous studies in Carajás (Presti et al. 2009), but not in the Pantanal, in which a synchronous breeding pattern was observed (Guedes 1993 \& 2009). The Psittacidae family is characterized by a marked hatching asynchrony (Vigo et al. 2011) and environmental factors, such as rain, temperature, and food resource availability may contribute to the asynchrony observed in Carajás (Presti et al. 2009) but not in other regions.

The clutch size observed in the present study was similar to that reported from the Pantanal region (Guedes 1993, Antas et al. 2010), where most nests contain two eggs and one chick. Factors, such as food availability, cavity availability, the ability of male macaws to feed nestlings, and competition may influence clutch size (Guedes 1993, Renton 2004, Djerdali et al. 2008, Antas et al. 2010). Furthermore, long-lived species, such as Hyacinth Macaws, generally experience higher adult survival rates and have smaller clutch sizes (Britt 2011).

The present study provides relevant ecological information about Hyacinth Macaws in the Amazon region, for which information of the species is scarce. Surveys in this region are financially and logistically challenging. Therefore, the data presented here represents an important contribution and is expected to facilitate conservation efforts. Understanding key ecological factors, such as nesting tree species, nest distribution, and nest characteristics, has implications for the conservation of the species. Knowing which tree species to preserve and where to best preserve them may be vital to the conservation of Hyacinth Macaws in the region. In 
addition, the information provided by the present study may contribute to the development of environmental education activities, which can promote a better understanding of the ecological needs of the Hyacinth Macaw and, thereby, promote its conservation.

The presence of Hyacinth Macaw breeding cavities in the mosaic of protected areas in Carajás and the surrounding areas and the characteristics of these cavities are important for our understanding of the ecological requirements of Hyacinth Macaws in the Amazon region. Hyacinth Macaws have a highly specialized niche, and the limited availability of suitable cavities within breeding sites may reduce local populations to critical levels, thereby affecting their local persistence (Guedes 1993, Johnson et al. 1997, Guedes \& Seixas 2002). Because habitat degradation is a major threat to many animal species, including Hyacinth Macaws (Johnson et al. 1997), land use in Carajás represents a major threat to the viability of the local Hyacinth Macaw population. As such, basic ecological information, such as that presented here, will facilitate local conservation efforts.

\section{ACKNOWLEDGEMENTS}

We are grateful to Eliane Vicente, Cecilia B. Toledo, Talita Aleixo, Ludimila Conrado, Helder Elias, Letícia Cespede, Thiago Filadelfo and Patrick Karassawa for their assistance with field work; to IBAMA and ICMBio staff, particularly Frederico Martins, Umberto Baldan, Luiz Pereira Rodrigues and Dezivaldo Ribeiro for providing enormous support by allowing us to access their properties; to FundiBio (Fundação de Biologia da UNESP/Botucatu) and the Hyacinth Macaw Institute for providing expertise on climbing and collecting nesting information; to members of the Hyacinth Macaw Institute for their generous assistance; to Vale for funding; and to Tarcísio Magevisk Rodrigues and Mayla Feitosa Barbirato for assistance. We are especially thankful to all landholders.

\section{REFERENCES}

Antas P.T.Z., Carrara L.A., Yabe R.S., Ubaid F.K., Oliveira-Jr. S.B., Vasques E.R. \& Ferreira L.P. 2010. A Arara-azul na Reserva Particular do Patrimônio Natural SESC Pantanal. Rio de Janeiro: SESC.

Antas P.T.Z. 2004. Pantanal guia de aves: espécies da Reserva Particular do Patrimonio Natural do SESC Pantanal. Rio de Janeiro: SESC.

BirdLife International. 2016. Anodorhynchus hyacinthinus. The IUCN Red List of threatened species. http://dx.doi.org/10.2305/IUCN. UK.2016-3.RLTS.T22685516A93077457.en (Access on 01 January 2016).

BirdLife International. 2018. Species factsheet: Anodorhynchus hyacinthinus. http://datazone.birdlife.org/species/factsheet/hyacinth-macawanodorhynchus-hyacinthinus (Access on 15 September 2018).
Britt C.R. 2011. Nest survival and nest-site selection of Scarlet Macaws (Ara macao cyanoptera) in the Maya Biosphere Reserve of Guatemala and Chiquibul forest of Belize. MSc. Dissertation. Las Cruces: New Mexico State University.

Cockle K.L., Martin K. \& Robledo G. 2012. Linking fungi, trees, and hole-using birds in a Neotropical tree-cavity network: pathways of cavity production and implications for conservation. Forest Ecology and Management 264: 210-219.

Coelho M.C.N., Monteiro M.A., Lopes A.G. \& Lira S.B. 2008. Regiôes do entorno dos projetos de extração e transformação mineral na Amazônia Oriental. Novos Cadernos NAEA 8: 73-107.

Conrado L.P. 2015. Relação da estrutura da paisagem mosaico Carajás, PA com a ocorrência de Anodorhynchus hyacinthinus (Arara-azulgrande). MSc. Dissertation. Sorocaba: Universidade Federal de São Carlos.

Cornelius C., Cockle K., Politi N., Berkunsky I., Sandoval L., Ojeda V., Rivera L., Hunter M. \& Martin K. 2008. Cavity-nesting birds in Neotropical forests: cavities as a potentially limiting resource. Ornitología Neotropical 19: 223-268.

Djerdali S., Tortosa F.S., Hillstrom L. \& Doumandji S. 2008. Food supply and external cues limit the clutch size and hatchability in the White Stork Ciconia ciconia. Acta Ornithologica 43: 145-150.

Dornas T., Barbosa M.O., Leite G., Pinheiro R.T., Prado A.D., Crozariol M.A. \& Carrano E. 2013. Ocorrências da Arara-azulgrande (Anodorhynchus hyacinthinus) no estado do Tocantins: distribuição, implicaçōes biogeográficas e conservação. Ornithologia 6: 22-35.

Guedes N.M.R. 1993. Biologia reprodutiva da Arara-azul (Anodorhychuns hyacinthinus) no Pantanal, MS, Brasil. MSc. Dissertation. Piracicaba: Universidade de São Paulo.

Guedes N.M.R. 2004. Management and conservation of the large macaws in the wild. Ornitologia Neotropical 15: 279-283.

Guedes N.M.R., Bianchi C. \& Barros Y. 2008. Anodorhynchus hyacinthinus. In: Machado A.B.M., Drummond G.M. \& Paglia A.P. (eds.). Livro vermelho da fauna brasileira ameaçada de extinção, v. 2. Brasília: Ministério de Meio Ambiente.

Guedes N.M.R. 2009. Sucesso reprodutivo, mortalidade e crescimento de filhotes de Araras azuis Anodorhynchus hyacinthinus (Aves, Psittacidae) no Pantanal, Brasil. Ph.D. Thesis. Botucatu: Universidade Estadual Paulista.

Guedes N.M.R. \& Seixas G.H.F. 2002. Métodos para estudos de reprodução de psitacídeos. In: Galetti M. \& Pizo M. (eds.). Ecologia e conservaçâa de psitacídeos no Brasil. Belo Horizonte: Melopsittacus Publicaçóes Científicas.

ICMBio. 2009. Plano de manejo da Reserva Biológica do Tapirapé. http:// www.icmbio.gov.br/portal/unidadesdeconservacao/biomasbrasileiros/amazonia/unidades-de-conservacao-amazonia/2000rebio-do-tapirape (Access on 08 October 2019).

Johnson M.A., Tomas W.M., \& Guedes N.M.R. 1997. On the Hyacinth Macaw's nesting tree: density of young Manduvis around adult trees under three different management conditions in the Pantanal wetland, Brazil. Ararajuba 5: 185-188.

Mannan R.W., Meslow E.C. \& Wight H.M. 1980. Use of snags by birds in Douglas-Fir forests, western Oregon. Journal of Wildlife Management 44: 787-797.

Martins F.D., Castilho A.F., Campos J., Hatano F.M. \& Rolim S.G. 2012. Fauna da Floresta Nacional de Carajás: estudos sobre vertebrados terrestres. São Paulo: Rona Editora.

Mittermeier R.A., Gusmão-Câmara I., Pádua M.T.J. \& Blanck J. 1990. Conservation in the Pantanal of Brazil. Oryx 24: 103-112.

Munn C.A., Thomsen J.B. \& Yamashita C. 1987. Population survey and status of the Hyacinth Macaw (Anodorhynchus hyacinthinus) in Brazil, Bolivia, and Paraguay. Lausanne: Report to the Secretariat of the Convention on International Trade in Endangered Species of Wild Fauna and Flora.

Palheta-da-Silva J.M. 2004. Poder, governo e território em Carajás. Ph.D. Thesis. Presidente Prudente: FCT/UNESP. 
Pinho J.B. 1998. Aspectos comportamentais da Arara-Azul (Anodorhynchus hyacinthinus) na localidade de Pirizal, município de Nossa Senhora do Livramento, Pantanal de Poconé. MSc. Dissertation. Cuiabá: Universidade Federal do Mato Grosso.

Pinho J.B. \& Nogueira F.M. 2003. Hyacinth Macaw (Anodorhynchus hyacinthinus) reproduction in the northern Pantanal, Mato Grosso, Brazil. Ornitología Neotropical 14: 29-38.

Pivatto M.A.C., Donatelli R.J. \& Manco D.G. 2008. Aves da fazenda Santa Emília, Aquidauana, Mato Grosso do Sul. Atualidades Ornitológicas 143: 33-37.

Presti F., Oliveira-Marques A., Silva G., Miyaki C. \& Guedes N.M.R. 2009. Notas sobre alguns aspectos da biologia da Arara-azul (Anodorhynchus hyacinthinus) (Psittaciformes: Psittacidae) na região do Carajás, Pará. Atualidades Ornitológicas 151: 4-7.

Presti F.T., Guedes N.M.R., Antas P.T. \& Miyaki C.Y. 2015. Population genetic structure in Hyacinth Macaws (Anodorhynchus hyacinthinus) and identification of the probable origin of confiscated individuals. Journal of Heredity 106: 491-502.
R Core Team. 2014. R: a language and environment for statistical computing. Vienna: R Foundation for Statistical Computing.

Renton K. 2004. Agonistic interactions of nesting and nonbreeding macaws. Condor 106: 354-362.

Rosa J.M. 2016. Arara-azul Carajás. Belo Horizonte: Nitro.

Santos-Jr. A., Tomas W.M., Ishii I.H., Guedes N.M.R. \& Hay J.D. 2007. Occurrence of Hyacinth Macaw nesting sites in Sterculia apetala in the Pantanal wetland, Brazil. Gaia Scientia 1: 127-130.

Sedgwick J.A. \& Knopf F.L. 1992. Cavity turnover and equilibrium cavity densities in a cottonwood bottomland. Journal of Wildlife Management 56: 477-484.

Snyder N.F., McGowan P.J.K., Gilardi J. \& Grajal A. 2000. Parrots: status survey and conservation action plan 2000-2004. Gland: IUCN Species Survival Commission.

Vigo G., Williams M. \& Brightsmith D.J. 2011. Growth of Scarlet Macaw (Ara macao) chicks in southeastern Peru. Ornitología Neotropical 22: 143-153.

Associate Editor: Eduardo S. Santos. 